\title{
The Omnibus Law Employment Copyright's Affected Legal Certainty on The Status of Outsourcing Workers
}

\author{
Rini Kartika ${ }^{1}$ \\ \{rini.kartika@outlook.com\}
}

${ }^{1}$ Doctoral Students of Law Science of Jayabaya University, Jakarta, Indonesia

\begin{abstract}
This research aims to know about the paradigm shift from the traditional work view that workers serve the system to the modern work view that the system must serve workers. Workers in Indonesia often say that outsourcing is "Slavery in the Modern Age". Every outsourced worker who has signed a certain agreement with an Outsourcing Labor Supply company, workers has automatically agreed to be placed in a company that needs their services and thoughts in accordance with the position required by the labor user company for a certain period. The methodology research in this study using empirical-normative legal research. The aim is to examines how people socialize to other in their community, this methodology can be considered as a sociological legal research. The government in terms of handling outsourced workers don't get legal certainty, when outsourced workers contract period has expires, they will be extended, and will continue for years, even decades.
\end{abstract}

Keywords: Workers, Outsourcings, Outsourced Company, Omnibus Law, Contract

Workers

\section{Introduction}

In Indonesia, outsourcing is likened to slavery in modern times. This is influenced by many factors, one of which is related to the Law of Economic Development. Indonesian and foreign entrepreneurs who invest their capital in Indonesia learn from their experiences in the golden era of former President Soeharto (the late), which resulted in riots everywhere. As a consequence, many businessmen who invested their capital in Indonesia returned to their respective countries. The production did not run as it should, the sales were not optimal, or even the absence of incoming profits. It led to a massive work termination. The problem was that employers were unable to pay severance pay for workers who have been loyal to work for years. Those conditions have led employers to look for solutions to avoid facing the similar incidents. They collaborate with the Labor Supply Company/Agency, which is in charge of screening job seekers in accordance with the criteria desired by company or employment labor user company, conducting payroll systems, over time payment, and insurance. The contract signing is only done between the labor supply company and labor user company. Therefore, the entrepreneurs are able to minimize their output.

A lot of entrepreneurs are looking for outsourcing company or outsourcing agency. On the other hand, many workers rely on their expertise and educational level to find jobs that suits on their educational background. However, in reality, the large number of job seekers are not entirely comparable to the company who search for job seekers. Therefore, the job seekers 
inevitably work not in accordance with their educational background and are willing to work under the auspices of outsourcing.

Indonesian workers consider that outsourcing is "Slavery in the Modern Age". It is because every outsourcing worker who has signed a Specific Time Cooperation Agreement (PKWT) with an Outsourcing Labor Supply company automatically has to agree to be placed in a company that needs its workers, services, and thoughts in accordance with the position required by the labor user company for a certain period of time until this agreement expires.

The Labor Law Act 13 Of 2003 article 59 paragraph 3, it is explained that the PKWT can be extended. The longest working period of PKWT is 2 years. The process of contract extension must be submitted to the company maximum 7 (seven) days before the contract expires. When the contract period expires but the target has not been fulfilled, the working period can be extended once again for no longer than 1 (one) year. If the second party (user) may still want the outsourcing workers to continue the agreement after the agreement has expires, then the second party have to make another new agreement with the outsourcing company. The outsourcing company needs to transfer the agreement to their subsidiary company in order to renew the agreement for 1 (one) month or 3 (three) at the most on behalf of the outsourced workers. There is a grace period of 30 days to renew the contract, and after that the outsourcing workers cannot be re-extended. Outsourcing companies must dismiss or appoint as permanent workers, but this has been distorted by the outsourcing company itself. It can be said that almost $60 \%$ of outsourced workers have been extended more than once placed in companies in their core business. This is a labor crisis in Indonesia. Despite the Constitutional Court Decree No. 27/PUU-IX/2011, outsourcing is even veiled than before. Therefore, the Government of Indonesia is trying to issue an Omnibus Law which can meet the legal certainty for all workers. This decree gives fresh air to the outsourcing workers hoping that outsourcing is removed.

\section{Method}

The methodology research used in this paper is an empirical-normative legal research method, seeing the law in the real sense and examining how the law works in the community. Since this study examines people in living relationships in society, the empirical legal research method as a sociological legal research which is taken from facts in a community, legal entity or government agency. The legal regulations become the primary legal material in this study. The primary data in this study are collected from the people's lives by means of interviews, observations, questionnaires, and samples.

\section{Result and Discussion}

Problems regarding outsourcing workers are quite varied. This is because the outsourcing in the business world in Indonesia is now increasingly widespread and has become a necessity that cannot be delayed by business actors. Meanwhile, the existing regulations are not yet sufficient to regulate this problem. In the outsourcing business, there are labor supply companies and labor user companies which are inseparable. They both provide benefits each other.

Labor Law must contain 3 (three) principles, namely: the principle of job security, job income, and social security. Some companies have certain businesses which contain high uncertainty. Thus, it is a big risk if the company directly appoints permanent employees. 
However, sometimes labor supply agencies often disobey Article 59 Paragraph 3 of the Labor Law Act 13 Of 2003.

Outsourcing workers consider that outsourcing should not be implemented in the short term. By employing the outsourcing workers, companies will certainly spend more money as a management fee to the labor supply agency. Thus, the outsourcing workers emphasize that outsourcing should be seen in the long term starting from the career development of the outsourcing workforce itself, efficiency in the field of labor, organization, and welfare of the outsourced workforce. By doing so, the labor user companies can focus on their core competencies in business. The internal supporting matters in a company are transferred to other parties such as a more professional labor supply company.

In developed countriy, such as the United States, outsourcing has become so global that it has become a means for companies to concentrate more on its core business i.e. more focused on product service excellence. However, the United States has very strict regulations regarding outsourcing. Once the outsourcing workers have completed the contract period, the company must choose whether the workers are appointed as permanent or dismissed from the company. If the company ignores labor regulations in the United States, by re-extending the contract, the United States Government will not hesitate to put sanction by "shutting down" the company. This makes sure the outsourcing workers not to lose their rights protected by the constitution. To avoid workforce exploitation, the Constitutional Court offers two types of contract models.

1. First, the employment agreement between the worker and the company must use a nonspecified time work agreement ("PKWTT") instead of a specific time work agreement ("PKWT").

2. Second, the company must apply transferring protection principle for the workers who work for companies with outsourcing system.

The Constitutional Court Decree allows two types of PKWT, namely conditional and unconditional PKWT. The conditional PKWT requires that outsourcing companies to transfer of protection of rights for workers if the work object remains in existence even though the contracting company or the company providing labor/labor services is replaced. Meanwhile, unconditional PKWT does not require the transfer of rights for workers. In the practice of outsourcing, there are workers who work dozens of years in a single work location even though the outsourcing company has changed. Sometimes, the owners of both companies are the same, only the company name is different.

The job seekers may said regarding outsourcing is a fact that is difficult to eliminate because not all companies in Indonesia are really ready to have permanent employees with all the consequences. Nowadays, the government has issued a series of economic policy packages to improve economic conditions that are currently slowing down. Basically, these packages provide legal certainty for investors who want to invest their capital in Indonesia, one of them is by increasing deregulation and de-bureaucratization of regulations to facilitate investment in both domestic investment and foreign investment such as providing facilities for 3-hour investment services, faster tax allowance and tax holidays, VAT exemptions for transportation equipment which are all contained in the Economic Policy Package starting from volume I to volume XVI. However, the power of the 16 volumes of the Economic Policy Package is inefficient. One of the causes of slowing investment is the inefficient Indonesian economy. ${ }^{1}$ It is also marked by Indonesia's Incremental Capital Output Ratio (ICOR) which also has not shown its role. ${ }^{2}$ 
ICOR of Indonesia is above the average of Asian countries which is in the range of 6 percent, and far enough compared to China which is above 8 percent. China's economic growth is high because the output produced is far lower than the input.

\subsection{Knowledge and Skill of The Human Resources}

In Indonesia, one of the fundamental factors that influence Incremental Capital Output Ratio (ICOR) is Human Resource (HR). The relatively low educational background and limited skills ${ }^{4}$ have affected the recruitment process of outsourcing workers. Almost every company has a quality standard of prospective workers that they will place in the company, surely the prospective workers must have criteria according to what they expect. The amount of labor force is large because demographics are still young, but are constrained by relatively low educational background and limited skills.

Every year, a lot of fresh graduates: bachelor, diploma, and even high school. Fresh graduates often do not have yet any expertise. They start the world of work really from the bottom. If the employers are not careful in recruiting, this will affected on the company. The higher the criteria of the entrepreneur, the more workers will not get a job. Those reasons have led the Government of Indonesia to issue Omnibus Law of Job Creation.

Omnibus Law is a change to a regulation at the same time in a short time, or a rule that is made based on the compilation of several rules that aim to combine, streamline, revoke the regulations so that it is right on target. The word omnibus is taken from Latin which means "for everything". Black Law Dictionary which is a reference to the definition of the term law in the West has also explained what omnibus lawis. In essence, this concept is like the saying once paddling, two or three islands are exceeded. Omnibus law is simply understood as a method of drafting rules, which in one regulation contains several materials/substances (which are usually made separately in several rules). When this regulation is enacted, it will revoke the rules or materials in other regulations that have been arranged.

In Black Law Dictionary, Omnibus Bill is: ${ }^{5}$

1. "a single bill containing various distinct matters. drafted in this way to force the executive either to accept all the unrelated minor provisions or to veto the major provisions"

2. "A law that contains a variety of materials formed to force the executive to accept all unrelated provisions or to veto the main provisions"

Omnibus Law is associated with the Constitutional Court Decision No. 27/PUU/2011, which contains:

DECISION

Adjudicate,

State:

Grant the Petitioner's request for in part;

The phrase "... work agreement for a certain time" in Article 65 paragraph (7) and the phrase "... work agreement for a certain time" in Article 66 paragraph (2) letter b of Law No. 13/2003 on Manpower (State Gazette of the Republic of Indonesia No. 39/2003, Supplement to the State Gazette of the Republic of Indonesia Number 4279) contrary to the 1945 Constitution of the Republic of Indonesia as long as the 47 work agreements do not require the transfer of protection of rights for workers/laborers whose objects of work remain, despite the change companies that carry out part of the work of other jobs from other companies or companies providing workers/labor services; 
The phrase "... work agreement for a certain time" in Article 65 paragraph (7) and the phrase "... work agreement for a certain time" in Article 66 paragraph (2) letter b of Law Number 13 of 2003 concerning Manpower (State Gazette of the Republic of Indonesia Year 2003 Number 39, Supplement to the State Gazette of the Republic of Indonesia Number 4279) does not have binding legal force insofar as such work agreement does not require the transfer of protection of rights for workers/laborers whose objects of work remain, despite the change of companies that carry out part of the work of part of the work other companies or companies providing workers/labor services;

Refuse the Petitioner's request for other than the rest;

Order to include this decision in the Official Gazette of the Republic of Indonesia as appropriate.

In its consideration, the Constitutional Court emphasized that outsourcing is a reasonable business policy of a company in the context of business efficiency. However, workers who work in outsourcing companies must not lose their rights protected by the constitution, even if they are transferred to other companies. However, in the Omnibus Law is not in line with the expectations of the outsourced workers, because it removes Article 59 of the Law No. 13/2003 regulating the work contract. When the article is abolished, all types of work are permitted and legitimate to employ laborers with a contract system. Therefore, the draft of the Employment Bill potentially causes all jobs to use the outsourcing system. ${ }^{6}$

\subsection{Omnibus Law as The Draft Of The Employment Bill}

Omnibus Law has deviated from one of the 3 (three) principles in labor law contained in the International Labor Organization, namely the principle of job security. If the draft of the Employment Creation Bill is passed, employers can make work contracts to the workers who work directly under it, as well as to outsourced workers placed at these companies. As a consequence, modern-day slavery will continue without end. This weakness is exploited by companies that need it or the company where they work. Efforts to reform the labor agreement so far is going nowhere. There are many problems occurs repeatedly has been found in the company and should be systematically solved, however it turns out to be deadlocked, blundered, and almost no solution.

In Indonesia, employers are taking an advantage in this situation. When the outsourcing workforce has expired its contract with an outsourcing agency, then the user companies state that they will still use the "services" of the outsourced workforce. However, it is constrained by the contract period expiring for 2 (two) years. Then, the labor supply agency transfers the workforce temporarily for 1 (one) month to another company, or a subsidiary company. After 1 (one) month, the workforce is withdrawn and asked to re-apply and do a psychological test, or other tests that are merely formalities. After that, the workforce signs a new Specific Working Time (PKWT). This does not only occur in one outsourcing company, but this has happened quite a lot in other companies. Even, there are the outsourced workers who have worked for decades as outsourced workers in the same company. This has been much distorted by labor supply companies with respect to labor regulations. The legal basis or the legal umbrella for manpower is bypassed as if workers are in dire need of work due to the current conditions.

In terms of daily practice, outsourced workers are always placed in the core business, for example, customer service, which is not in accordance with Article 59 of Labor Law ACT 13 Of 2003, since customer service is the core business in Banking system, which is carried out continuously. In the reality, the outsourced workers are commonly working for the Bank, and 
they have been placed as customer services. It can be seen from the employee ID card showing the logo of the company where they actually work for. This means that they are outsourced workers.

In 1997, Indonesia experienced a severe economic crisis and the boredom to the New Order government led by the Suharto which ran in unstable politics leading to step him down. The economic situation which was not getting better and the desire to implement a democracy became the reasons for the community to ask for a change of leader. Forms of outsourcing and contract labor relations are ways to realize a flexible labor market that will create production efficiency and maximize capital gains.

Labor market flexibility refers to the speed at which the labor market adjusts for fluctuations and changes in society, economy or production. This ability to adapt causes labor market institutions to achieve a sustainable balance.

The flexibility of the labor market is an idea in changing the labor system which has been considered rigid by employers. The flexibility of the labor market is one way to help the government reduce unemployment and expand employment opportunities. Changes to the labor system will always change to a more flexible direction when the existing work system has been considered a rigid and unprofitable system for employers.

According to the literature review on the application of labor market flexibility, there are three positive impacts on economic growth, namely:

(1) There is competition;

(2) a company that gets the convenience to recruit and lay off workers;

(3) a work relationship based on a contract and outsourcing system as well as working hours and wage rates that can be adjusted to the business cycle.

When the Government of Indonesia wants to enact this Omnibus Law, it is easily actualized because Government of Indonesia Regulations, Presidential Regulations, and Ministerial Regulations are made by executive power (under the authority of the President). It is different from with laws made by the House of Representatives. The coordination flow is longer, even there is a process of political tugging.

Whereas in the United States of America, establishing the law is made through a package of policies, for example the law of investment does not only regulate the investment procedure, but also regulates the licensing process, labor, land transfer process, and so on. Therefore, the investors' rights and obligations can be found in one legal document, with a large number of articles. Meanwhile, in Indonesia, there are regulations overlapping each other.

\section{Conclusion}

The large number of job seekers (prospective workers) in Indonesia is not comparable with the number of companies seeking for employees. A lot of fresh graduates who explore the world of work and look for a job finally find a job which does not match their educational background. Thus, they have to accept the job with work experience from the very bottom level. On the other hand, a lot of companies make strict requirement for the position offered. It is related to the income of companies that are used to pay workers.

It is considered that the government is not serious to overcome the problem of outsourcing. This leads the workers do not have legal certainty. In this case, the Government cannot implement the 3 (three) labor principles as stipulated by the ILO. Thus, when the work contract ends, it will be extended for years, even decades. It can be said that the Government does not reduce contract labor which is basically not in accordance with the 1945 Constitution. 
As a result, the outsourcing workers follow the "market flexibility" system meaning that they have no other choice to work in a particular company with an outsourcing system.

\section{Acknowledgments}

The author would like to thank and give an appreciate to the Head of Semarang State University for providing a facility to join International Conference in ICILS 2020.

\section{References}

[1] Wiratraman, R. Herlambang Perdana, "Hak Buruh, Revisi UU 13/2003 Dan Imperialisme Global", Surabaya Post, 2006 website article (2006)

[2] Garner, Bryan A, Black's Law Dictionary 10th Edition, West Group, 2014

[3] Nugraheny, Dian Erika, "5 Aturan Dalam RUU Cipta Kerja Yang Berpotensi Memiskinkan Buruh", 2020, website article (2020)

[4] Nugroho, Hari Wahyu, and Indrasari Tjandraningsih, seminar "Fleksibiltas Pasar Kerja Dan Tanggung Jawab Negara," Bandung (2007)

[5] Pakpahan, Muchtar, and Ruth Damaihati Pakpahan, "Konflik Kepentingan Outsourcing Dan Kontrak Dalam UU No. 13 Tahun 2003 "Jakarta: Bumi Intitama Sejahtera (2010)

[6] Standing, Guy, Global Labour Flexibility: Seeking Distributive Justice, Palgrave Macmillan UK, 1st edn (London: Palgrave Macmillan UK, 1999) 